\title{
INTRODUCTION
}

\section{Cultures of Bohemia in the Twentieth Century}

PETER ZUSI

University College London, School of Slavonic and East European Studies, UK

THE PRESENT DOUBLE-ISSUE of Central Europe is a special issue, yet not precisely a 'themed' one. In contrast to recent themed issues of the journal ('Remembering Dictatorship' [12.1]; 'Psycho-Active Substances in Central European History and Culture' [12.2]) the articles assembled here do not centre on a shared topic or set of questions but present a variety of approaches to thinking about different aspects of culture in the Czech lands in the twentieth century. This issue may be understood loosely as a companion to Central Europe 5.2 (2007), focused on 'Bohemia 1945'.

Whilst the selection here does not aim to provide completeness or coherence in the usual sense of a themed issue, this does not mean the articles have nothing in common beyond geographical focus. For all of the contributions approach the complexity of cultural questions in this region along interstices dividing traditional scholarly disciplines. Multi- and interdisciplinarity, naturally, are not unfamiliar academic ideals. Yet in the case of twentiethcentury Bohemia — a region associated with 'interstitial spaces' in geographic, national, linguistic, ethnic, and cultural senses - interdisciplinarity emerges as a particularly apposite challenge. Through inventive combination of discursive approaches drawn from art history and visual studies, literary criticism, history, political philosophy and cultural studies, the contributions to the present issue respond to this challenge and attest to innovative recent developments in scholarship on and from this region. 
The first two contributions represent different ways of approaching questions of gender in early twentieth-century Czech culture. Jitka Malečková explores the gendering of nationalist discourse and ethnic stereotypes in Czech literature of the period. Her article realigns the expected relations between nationalism, gender, and ethnic minorities (in this case, Jews and Romani) by examining how several of the most prominent Czech women writers of the early twentieth century presented figures of the Other in their stories and novels. She weighs carefully other scholars' claims regarding the intersection of gender and nationalism in modern Czech culture, and most prominently Robert Pynsent's argument that, in the early twentieth century, Czech women writers, surprisingly, often evinced more pronounced antisemitic tendencies than their male counterparts. Jindřich Toman then explores the construction of what might be called a 'modernist masculinity' in 1920s Czechoslovakia, using the now little-known lifestyle magazine Gentleman as a case-study. Rather than extrapolate a single, coherent ideal of masculinity from this material, however, Toman examines the multifaceted — and often conflicting — prescriptions and proscriptions this magazine presented to its (primarily) male readership. Bringing discursive analysis together with a thorough understanding of the history and function of popular graphic media, Toman argues that this lifestyle magazine presented readers with a user-friendly form of 'conversational modernity' that lies somewhere between the instructional and the represented.

Tomáš Jirsa also analyses intersections between the visual and the textual, applying architectural and spatial modes of interpretation to Franz Kafka's Der Process (The trial, pub. 1925). To the degree that this canonical modernist novel has previously been 'read' in spatial terms, this has generally occurred with a focus either on the various attics/law courts through which Josef K. wanders as in a labyrinth, or on the urban topography of the modernizing city (generally understood as a thinly disguised Prague) where centre and periphery have entered 
into an uncertain and confusing exchange of roles; in either case the emergence of what might loosely be called non-Euclidean narrative geometry has appeared fundamental to the modernism of Kafka's great novel. Jirsa proceeds differently. The paradigmatic space in his interpretation is the Gothic cathedral, embodying a particular form of ornamentalist discourse, in which what is arguably the climactic chapter of the novel is set. Neither bureaucracy nor metropolis, but the archteypal monument to medieval spirituality becomes in Jirsa's reading the stage for Josef K.'s distinctly modern dilemma.

The next two articles brush against the grain of the cultural-political oppositions through which the history of this region in the twentieth century is commonly understood. Tim Beasley-Murray offers a provocative examination of some surprising conceptual continuities in the career of perhaps the most influential Czech literary scholar of the twentieth century, Jan Mukařovský. One of the most original thinkers associated with 'Prague Structuralism' in the 1930s, Mukařovský - to the consternation of many of his students at the time and since — made peace and indeed actively cooperated with the Stalinist regime after 1948 , in the process renouncing his earlier, ground-breaking work. Beasley-Murray examines this development not simply as a personal or political shift, but in order to explore latent ambivalences in Mukařovský's structuralist essays of the 1930s towards 'avant-gardist' aesthetic categories. In particular, an inclination towards holistic systems and an 'aesthetics of order' constitute, in Beasley-Murray's reading, a foundation for Mukařovský's later turn. By no means a denunciatory gesture, Beasley-Murray's interpretation aims rather to show the complexities lurking within aesthetic and political positions that are routinely understood to stand in sharp opposition.

Similarly, Jiřina Šmejkalová's investigation into the career and vicissitudes of two Czech explorers, authors, and film-makers challenges pat dichotomies opposing cultural conformism and resistance in Socialist Czechoslovakia. The books and films that Jiří 
Hanzelka and Miroslav Zikmund produced from material gained during their extraordinary expeditions across the globe made them so famous in the 1950s and 1960s that they were widely known in Czechoslovakia simply as 'H\&Z'. Without doubt, the Communist cultural authorities supported this fame and exploited it for their own purposes, with the tacit approval (at the least) of Hanzelka and Zikmund. But once their political loyalties towards some form of reform socialism became more blatant over the course of the 1960s, Hanzelka and Zikmund found themselves banished from the public sphere from 1968 until the regime fell in 1989. Šmejkalová investigates the ways this curious 'command celebrity' of 'H\&Z' straddled socialist ideology and capitalist consumerism, political affirmation and cultural critique.

Geoff Chew's essay begins as an examination of one of the most striking Czech novels of recent years—Jachym Topol's Chladnou zemí (2009), translated as The Devil's Workshop (2013) — but expands into a reflection upon the uses and limitations of historiographical as opposed to literary representation of the Holocaust. Topol belonged to the youngest generation to be associated with the 'classic' dissident movements of the 'Normalization' era in Czechoslovakia. Presenting Topol's novel as a sharply sceptical portrayal of 'dissident', as opposed to official, forms of memorializing unrepresentable acts, Chew reads Topol's novel as itself constituting a considerably more successful instance of a 'dissident' mode of memorialization. Via discussion of forms of muzealization and even the narrative structure of video games, Chew concludes with a comparative analysis of Topol's novel and Timothy Snyder's influential Bloodlands (2010).

The issue concludes with Lucy Duggan's report on an international conference on 'Prague figurations of Jewish modernism' held in Tübingen earlier this year; Egbert Klautke's review essay on recent secondary literature re-considering the classic 'fin-de-siècle 
Vienna' topos; and a full section of book reviews, the first group of which relates to the focus of this special issue. It is hoped that, as a whole, the issue bears witness to an 'outward turn' in current bohemistika (or Czech studies) — towards addressing questions and quandaries particular to Czech or Czechoslovak cultural history whilst integrating these with intercultural and multidisciplinary contexts. Rather than a province for specialists, this bohemistika speaks multiple languages, assumes various guises, and seeks new interlocutors.

Finally, I would like to take this opportunity to announce on behalf of the editors the names of new members of the Central Europe Editorial and Advisory Boards. Joining our Editorial Board are Uilleam Blacker (UCL-SSEES), Peter Bugge (Copenhagen), Klara Kemp-Welch (Courtauld), and Jan Kubik (UCL-SSEES). Joining our Advisory Board are Ulf Brunnbauer (Regensburg) and Martin Schulze Wessel (Munich). We are extremely pleased to welcome these colleagues to the Boards, and look forward to working together fruitfully on future issues. 